Policy Research Working Paper 1465

Post Trade Liberalization Policy and Institutional Challenges in Latin America and the Caribbean

Sarath Rajapatirana

The World Bank

I.atin America and the Caribbean

Technical Department

Advisory Group

May 1995
To maintain liberal trade and advance the agenda for more open trade, economic policy must prevent external shocks from becoming crises - and protection must remain uniform among sectors. Trade policymaking institutions must be able to deal with changes in political equiliorium resulting from external shocks or the lobbying power of groups seeking exceptions from uniform protection. 
Policy Research Working Paper 1465

\section{Summary findings}

Argentina, Chile, Colombia, Jamaica, Trinidad and Tobago, and Uruguay undertook extensive trade reform at a time of crisis, at which time institutional reform was difficult to undertake. Many of the countries had become members of the General Agreement on Tariffs and Trade (GATT) in the late 1980s and anticipated institutional reform. Only later did they reform trade policymaking institutions to bring them somewhat in line with trade policy regimes and GATT rules.

These countries have all used reference prices and antidumping provisions of the GATT, rather than safeguards, to provide relief from import surges. They have all tried to centralize trade policy by moving it from different agencies into a single agency. Despite liberalization, some sectors - including automobiles, textiles, and agriculture - remain protected.

Lessons Rajapatirana draws from experience in these countries:

- The deteriorating macroeconomic situations are the main challenge to maintaining open trade policy.

- Trade policymaking must be constantly reviewed to prevent reversals, and the costs of protection must be communicated to the public at large.

- There must be short-run measures to help domestic activities adjust to short-run price movements and alleviate pressure for protection. The danger: such measures (unrelated to long-run price trends) can become permanent.

- External commitments (through the WTO or customs unions) can be used to discourage a return to protection.

- Extending reform (to labor and capital markets and the regulatory framework) will help maintain and extend trade liberalization. Allowing factors of production to move smoothly from one activity to another could help prevent the buildup of pressures that lead to protection.

- An institution to consider exceptional protection should be advisory (independent of day-to-day trade policymaking), so that it works steadily, free from administrative pressures and exigencies. Requests for protection must be handled openly and transparently, with the findings subject to public scrutiny. Procedures for granting relief through safeguards and similar mechanisms must reflect all interests, including those of consumers, exporters, and users of the product.

- The analysis to establish injury must conform to high technical standards. The criteria to consider trade policies must reflect national interests, not those of any particular sector.

This paper - a product of the Advisory Group, Latin America and the Caribbean Technical Department - was presented at a conference held on March 29-31, 1995 at Port of Spain, and organized jointly by the Caribbean Agriculture Research Development Institute, the Technical Centre for Agricultural and Rural Cooperation (The Netherlands), and the Ministry of Agriculture, Land, and Marine Sciences of the Government of Trinidad and Tobago. Copies of this paper are available free from the World Bank, 1818 H Street NW, Washington, DC 20433. Please contact Joy Troncoso, room 18-314, extension 37826 (25 pages). May 1995.

The Policy Research Working Paper Series disseminates the findings of work in progress to encourage the exchange of ideas about development issues. An objective of the series is to get the findings out quickly, even if the presentations are less than fully polished. The papers carry the names of the authors and should be used and cited accordingly. The findings, interpretations, and conclusions are the authors' own and should not be attributed to the World Bank, its Executive Board of Directors, or any of its member countries. 


\title{
Post Trade Liberalization Policy and Institutional Challenges in Latin America and the Caribbean
}

\author{
Table of Contents
}

Page No.

Summary $\ldots \ldots \ldots \ldots \ldots \ldots \ldots \ldots \ldots \ldots \ldots \ldots \ldots \ldots \ldots \ldots \ldots$

I. Introduction $\ldots \ldots \ldots \ldots \ldots \ldots \ldots \ldots$

II. Post Trade Liberalization - Analytical Issues $\ldots \ldots \ldots \ldots \ldots$

III. Nature of the Trade Liberalizations $\ldots \ldots \ldots \ldots \ldots \ldots$

IV. Post Trade Liberalization Experiences $\ldots \ldots \ldots \ldots \ldots \ldots$

V. Lessons and Remedies $\ldots \ldots \ldots \ldots \ldots \ldots \ldots$

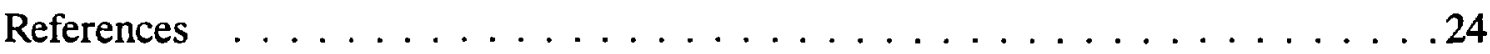





\section{Summary}

The paper examines the experiences of Argentina, Chile, Colombia, Jamaica, Uruguay and Trinidad and Tobago in broad terms to identify the post trade liberalization policy and institutional challenges, using examples of the evolution of trade policies and institutional arrangements in these countries to illustrate the main issues.

The challenges to maintaining liberalized trade regimes and advancing the agenda for more open trade depend both on the existing policy framework and the institutional set up. On the policy front, the requirements are to devise the means to prevent external shocks from turning into crises and to maintain the policy regime steadfast in terms of uniformity of protection among sectors. On the institutional front, the task is to reform and create institutions that can deal with the challenges arising from

changed political equilibrium due to both external shocks and the building up of lobbying power of some groups over others to secure for themselves a departure from uniformity in protection.

While the trade reforms were extensive, none of the countries reformed their institutional arrangements for trade policy making at the time of these reforms. As trade liberalizations were undertaken at times of crises, institutional reforms were difficult to undertake at the same time. Also, many of the countries had become GATT members in late 1980s and were anticipating future institutional reforms. It was only later that institutions were reformed to bring about some degree of conformity of trade policy making institutions with the trade policy regimes.

The institutional reforms lend themselves to a few generalizations. First, institutional reforms followed trade policy reforms. Second, there was an attempt to centralize trade policy making by moving it from different agencies to a single agency. Third, despite the liberalizations, some sectors such as automobiles, textiles and agriculture continued to be protected. Fourth, these countries have used reference prices 
and anti-dumping rather than safeguards to provide relief from import surges. Fifth, many countries mado their institutions more consistent with GATT rules.

Few lessons arise from the experience of these countries. First, the largest challenge to maintaining open trade regimes on the policy side arises from the macroeconomic situation. Second, trade policy making has to be kept under constant review if reversals are to be avoided and the cost of protection must be publicized and communicated to the community at large. Third, there must be measures that help with the adjustment of domestic activities to short run price movements that do not lead to protection. The danger is that these measures can become permanent and unrelated to long price term trends. Fourth, external commitments can be used to discourage a return to protection through GATT bindings and Common External Tariff agreements (CET) under customs unions. Finally, a continuing reform agenda that extends beyond trade policies and includes elements of labor, capital markets and the regulatory framework would help to maintain liberalized trade regimes and push the trade agenda further. Factors of production, if allowed to move from one activity to another smoothly, could prevent the build up of pressures that lead to protection.

The design of an institution to consider exceptional protection should have the following characteristics: First, make it advisory, independent of day to day trade policy making so that it could conduct its work in a steady manner, free from administrative pressures and exigencies. Second, inquiries into the requests for protection must be conducted in an open and transparent manner and the findings of such inquiries must be subject to public scrutiny. Third, the procedures for granting relief such as through a safeguard mechanism must reflect all interests and parties including consumers, exporters and users of the product in question as an input. Finally, the analysis used to establish injury must conform to high technical standards and the criteria used for considering trade policies must always reflect national interests and not that of any particular sector. 


\section{Post Trade Liberalization Policy and Institutional Challenges in Latin America and the Caribbean}

\section{Introduction}

With the strong trade reforms in the late 1980 s and early 1990 s, many countries in the Latin America and the Caribbean region are facing new policy and institutional challenges. On the policy front there are two major challenges. The first is to maintain open trade regimes in the face of continuous pressure to protect one sector or another. The second is to push the trade liberalization agenda further especially in the light of new opportunities for increasing trade with improved market access provided by the Uruguay Round. On the institutional front, the challenges are to adopt existing institutions that were the products of a bygone era of protection to a new era of more open trade and to modernize the trade policy making institutions to reflect the changed rules of international trade following the Uruguay Round. The policy and institutional challenges are closely released.

This paper attempts to identify these policy and institutional challenges at the national level for a selected group of Latin American and Caribbean countries, against the backdrop of existing trade regimes that came into being in the last ten years. Not all trade liberalizations were complete. Few sectors continued to be protected and many institutions that were conceived in an earlier era such as trade policy making agencies, procedures and decision mechanisms, rules, laws and regulations have continued. Many of the trade policy related institutions and their processes remain out of step with freer trade. The paper notes that new forms of protection have emerged that attempt to replace the more traditional measures. In the wake of policy reforms, many countries have attempted to improve their trade policy making institutions with varying degrees of success. The paper notes the experiences at the time of trade liberalization, some partial reversals of policy since then and identifies the attributes that are needed to meet the challenges of maintaining open trade regimes and advance the agenda for further liberalization. 
The paper examines the experiences of Argentina, Chile, Colombia, Jamaica, Uruguay and Trinidad and Tobago in broad terms so as to identify the post trade liberalization challenges, using examples of the evolution of trade regimes and institutional arrangements in these countries to illustrate the main issues.

Following this introduction, Section II identifies the analytical issues that are relevant to examine the post trade liberalization challenges. Section III examines the nature of the liberalizations and the extent to which the present challenges are rooted in those liberalizations. Section IV recounts the post trade liberalization experiences of the six countries in terms of policy reforms and institutional changes. Section $\mathrm{V}$ draws a number of lessons and remedies to maintaining and advancing the trade liberalizations achieved in the past decade.

\section{Post Trade Liberalization - Analytical Issues}

Trade liberalization involves the replacement of quantitative restrictions with tariffs, reduction of those tariffs to lower protection, reduction of the variance in protection across activities and increasing the transparency of trade policy making. These measures are intended to provide clear signals to current and potential investors in the tradeable sector regarding the continuance of the liberalized regime. This latter point would depend very much on the institutional environment for trade policy making. Who makes trade policy, what are the rules and procedures involved? Which institutions consider the request for protection and departures from uniform protection? In what form is relief granted to domestic industry in times of distress? These are important analytical issues on the institutional side. They are less well understood than issues on the policy side.

The issues in trade policy making have been well understood during the past twenty five years, due to the very successful analytical efforts put in by a group of highly distinguished trade theorists. ${ }^{1}$ There has been since, a growing consensus that the contribution of liberal trade

\footnotetext{
' See for instance the work of Corden (1974), Little, Scitovsky and Scott (1970), Jagdish Bhagwati (1978) and Anne O. Krueger (1978)
} 
regimes for efficiency lies equally if not more on the uniformity of protection rather than its level. While there is an obvious trade-off between the level and the variance in protection akin to the mean variance issue in statistical analysis, there is a growing consensus that reducing the variance in protection would deserve a greater weight than a low mean. ${ }^{2}$ This arises from the fact that the variance of protection is both a product of political economy elements at play during a liberalization process as well a factor behind the spread of protection from particular sectors or activities to others. ${ }^{3}$ The logic of this proposition is clear. If all sectors had the same lobbying power, then the variance could be either small or zero (a uniform tariff case), but giving equal protection to all has no benefit to any sector or activity. If some sectors are able to secure higher protection than others, the variance would increase. The ability to resist pressures to protect some sectors more than others is the key challenge. Here, institutions come to play a major role. Solid institutions that are created to balance the interests of all are an antidote against reversals in trade policies.

The outcome of a trade liberalization reflects the strength of national interests triumphing over sectoral interests. In the lexicon of political economy analysis, this outcome reflects at a given point in time, the clearing of the market for protection. Protection is demanded by different interest groups, whether they be a given sector, or a well identified pressure group such as labor. The price of protection is what society pays in terms of the resultant misallocation of resources with its negative impact on economic growth over time. That price can be reduced when both supply and demand for protection are made to intersect at a low price, so that the resource costs of protection are minimized. The particular balance of interests that lead to a liberalization in the first place can shift over time. This shift can be due to some exogenous event, such as an external shock that leads to an appreciation of the exchange rate or a change in government, (a political shock). Or it could be endogenous, like the increase in protection that can take place through a gathering of momentum for protection from

2 Variance in protection drives wedges among activities and interferes with the allocation of resources based on comparative advantage.

3 Sebastian Edwards "Openness, Trade Liberalization and Growth in Developing Countries" Journal of Economic Literature, vol. 31, (September 1993) pp. 1358-1393. 
an incomplete liberalization of the past, where some interests were able to garner political support to bring about a departure from uniformity by lobbying and changing the balance of interests that had led to the trade liberalization in the first place.

Nearly all the cases of trade liberalizations in the 1980s and 1990s were undertaken during periods of huge macroeconomic crisis, the resulting unavailability of foreign exchange to support an overvalued exchange rate and when policy choices were highly circumscribed. These crises helped to concentrate interests in reforming governments to put national interests over sectoral interests. The availability of balance of payments support such as those from the multilateral financial institutions that underwrote these trade liberalizations did help, but the trade liberalizations could not have taken place without the national interests becoming dominant, resulting in a shift in power to those who favor reform and away from those who were opposed to it. The dominance of national interests is reflected in the reduction in protection and the reduction in its variance.

Some sectors have continued to receive protection reflecting their powerful representation in the policy making bodies and the political clout that is generally wielded through the threat of huge distuptions arising form large unemployment, unavailability of key goods and services and simply through the importance of a particular constituency due to historical reasons.

It must be clear then that the challenges to maintaining the liberalized trade regimes and advancing the agenda for more open trade depends both on the existing policy framework and the institutional set up. On the policy front, the first requirement is to devise the means to avoid crisis. Or to put it differently, to prevent external shocks from turning into crises. The second challenge is to maintain the reformed policy regime steadfast in terms of uniformity of protection among sectors. On the institutional front, the task is to reform and create institutions that can deal with the challenges arising from changed political equilibrium due to both external shocks 
and the building up of lobbying power of one group over the others to secure for themselves a departure from uniformity. ${ }^{4}$

\section{The Nature of the Trade Liberalizations}

The late 1980 s and early 1990 s saw many trade liberalizations in Latin America and the Caribbean. While there had been trade liberalizations in the past, these liberalizations were different from them in a number of respects. First, the trade liberalizations had gone more deep and wide compared to the past. Second, they were based on the change in the ideology that came about in the 1980s which favored free markets and consequently liberal trade over restrictive trade. Third, the reforms were undertaken during huge adverse macroeconomic shocks, which was a departure from the past, when the reaction to adverse shocks was to tighten trade policies rather than to liberalize them ${ }^{5}$. Finally, many accompanying reforms were undertaken with the trade reforms, such as devaluation of the exchange rate, reduction of fiscal deficits, deregulation and privatization of the many public enterprises.

Of course not all countries liberalized their trade regime to the same extent. This was to be expected given the importance that pressure groups play in the process. Nonetheless, the overall trade reforms were substantial compared to any other period in post World War II history of the countries in Latin America and the Caribbean. The reforms of the six countries discussed here are representative of the trade reforms of the region.

In 1991, Argentina reduced average tariff rate to $15 \%$ and the variance in tariffs to a 5 $22 \%$ range, and reduced the coverage of quantitative restrictions (QRs) from $62 \%$ of domestic production in 1987 , to a few items. Chile has the best record for trade liberalization in Latin

\footnotetext{
${ }^{4}$ If all groups are able to lobby equally, then there cannot be a departure from uniformity. If no one is favored then all are favored. That is, if every sector were to receive the same extent of protection then no one is protected relative to the others. This is eloquently expressed in a line of a song from Gilbert and Sullivan's, Pirates of Penzance, "If everybody is somebody, then nobody is anybody".

${ }^{5}$ See I. M. D. Little, Richard N. Cooper, W. Max Corden and Sarath Rajapatirana "Boom, Crisis and Adjustment: Macroeconomic Experiences of Developing Countries," Oxford University Press, Oxford, 1993.
} 
America (see Table 1). By 1991 it had reduced its average tariff to $11 \%$, the variance in tariffs to virtually zero and eliminated nearly all the quantitative restrictions except for those needed for health and national security reasons. Similarly, Colombia carried out a strong trade reform in 1992 , accelerating the rate at which it had been bringing down protection, reducing the average tariff level to $12 \%$, the variance in tariffs to a $5-22 \%$ range and reducing QRs to less than $1 \%$ of its imports. Uruguay reformed its trade regime substantially in 1992. It reduced the average tariff level to $18 \%$, the tariff range to a $12-24 \%$ range and eliminated nearly all its $Q R s$.

The two Caribbean countries considered here, Jamaica and Trinidad and Tobago also saw strong trade reforms in the early 1990s. Jamaica reduced it average tariff level to $20 \%$, the tariff range to $0-45 \%$ and maintained QRs on only 3 import items. Trinidad and Tobago, reforming at a less rapid rate, reduced its average tariff also to $20 \%$ in conformity to the Caribbean Community (CARICOM) schedule, a tariff range of $0-45 \%$ and reduced QRs considerably through a negative list which applied to $40 \%$ of import items. Like other Caribbean countries, these two countries maintained non-tariff barriers in the form of stamp duties, surcharges and differential consumption taxes. But there is no doubt that the early 1990 s saw the trade regime of these two countries more open than any other time in the post World War II period.

While the trade reforms were extensive, there were many sectors that continued to be protected even in the strongly liberalizing countries. This is not surprising in the light of the political economy forces at work that define the contours of policy making. The variety of experiences among the countries considered here - Argentina, Chile, Colombia, Jamaica, Uruguay and Trinidad and Tobago - provide some scope for generalization as to why some sectors were protected even though the effort to liberalize was extensive.

In the case of Argentina, two sectors and two regions continued to be protected despite the strong reforms. The sectors were automobiles and textiles and the regions, Tierra del Fuego and certain parts of Patagonia. The two sectors were not competitive by any standard, and carried political clout due to their strong connections to past governments in the case of automobiles and to strong labor unions in the case of textiles. One additional fact relevant to 
textiles is that since Argentina's textiles face quota restrictions in the US under the Multi Fibre Arrangement there is a pre-disposition towards restrictions in the sector not only on the export side, but also on the import substitution side. In the case of the protection of the two regions, the use of trade policies might be considered an expedient, if harmful, substitute for regional development policy measures. It is worth noting that agriculture is not protected in Argentina because of its substantial comparative advantage arising out of its land rich resource base. ${ }^{6}$ Instead, agriculture is taxed in Argentina. Both nominal protection and producer subsidy equivalent of support to agriculture were consistently negative. ${ }^{7}$

Chile, the strong liberalizing economy has continued to protect domestic agriculture through a system of reference prices. A floor price and a ceiling price are established for few agricultural imports. These prices are based on a sixty month moving average. When the CIF import prices fall below the range, duties are imposed to equate to the difference between the CIF import price and the domestic floor price. If the CIF price rises above the ceiling price, then reference price is reduced to ceiling price level. During the 1990s, when international agricultural prices fell, Chilean farmers producing a limited range of goods for the domestic market were protected through the reference prices. This type of protection was associated with the effort to stabilize farm incomes when prices were falling and with the difficulties inherent in moving farmers away from producing traditional crops. At the same time that domestic import substituting agriculture was protected, Chile was blazing a new trail with its tremendous success with export agriculture which was not protected. Chile was able to increase its agricultural exports by some ten fold in less than ten years.

Colombia also continued to protect agriculture despite its trade reforms, which were among the fastest in the region. In fact, Colombia followed Chile in adopting a reference price system to protect agriculture, presumably for the same reasons as that of Chile. Ad valorem

\footnotetext{
${ }^{6}$ It has been shown that the factor content of Argentina's exports is dominated by natural resources (in this case, land), confirming the Heckscher-Ohlin model of trade that countries export goods intensive in the abundant factor. See Julio Berlinski "Post Trade Liberalization Institutional Issue in Argentina," Turcato Di Tella Institute, Buenos Aires, 1994.

i Valdes and Schaeffer, 1993.
} 
import duties of $15-20 \%$ range are imposed on some eight commodities (powdered milk, wheat, barley, white and yellow maize, rice, sugar and sorghum). Price bands for these commodities are based on a five year moving average of world prices where, the floor and ceiling price are established every six months on the basis of monthly international price quotations. Every two weeks minimum prices are fixed by the Ministry of Agriculture based on international price quotations. The duties paid on these eight items depend on the relationship of the import price and the floor and ceiling prices of the band. In addition to the regular ad valorem tariff imposed on the imports of these commodities, a specific duty is imposed to raise the import price to the minimum price. Thus, a type of variable levy is imposed on all the eight products.

Consequently, agriculture producers enjoyed high income at the expense of consumers. ${ }^{8}$

Jamaica's trade reforms left a number of exemptions, and the protection of some sectors continued. The vehicle for this was the exemptions from the regular tariff schedule at the time of the main trade liberalization (1991) and later the exemptions from the CET of CARICOM. The exemptions applied to agriculture where a stamp duty was imposed at rates of $35-90 \%$ compared to the CET of $20 \%$. There were also other items subject to protection through differential consumption taxes. These were automobiles, some agricultural imports, film industry imports and purchases prescribed by the authorities from time to time.

Trinidad and Tobago also maintained agriculture protection at the time of the trade liberalization. The main vehicle was surcharges imposed on agriculture imports. The other vehicles were stamp duties, different valuation bases and differential consumption taxes to continue the protection of some sectors. Consequently, there were substantial exemptions from the CET of $20 \%$. In $1992,92 \%$ of the QRs imposed on manufactured goods were removed.

Uruguay was slow in liberalizing its trade regime compared to the other southern cone countries. It continued to protect automobiles. It also continued to use reference prices to protect many manufactures that would face strong competition, such as cement. It is in the

8 Valdes and Schaeffer, 1993. 
process of converging its tariffs to the CET established by MERCOSUR which has four ranges from 5-20\%. Like Argentina, Uruguay did not protect agriculture because of its comparative advantage in agriculture arising from the rich land resources.

\section{Institutional Arrangements}

The continuance of protection at the time of liberalization reflected the particular power of an industry or a sector to lobby to alter the political equilibrium. This was facilitated by the institutional arrangements for trade policy making that existed at the time. Such arrangements include institutions which made trade policy, the rules and procedures that were followed and the procedures to consider requests for protection from import surges. These arrangements determine the extent to which departures from uniformity took place along with the different lobbying interests. In other words, institutional arrangements influence the supply side of protection while lobbying power of different activities and sectors determine the demand side.

None of the countries reformed their institutional arrangements for trade policy making at the time of the trade liberalization. Many reasons can be adduced for this outcome. First, since trade liberalizations were undertaken at times of crises, there was little opportunity to reform the trade policy making institutions at the same time. Second, institutional reform is as difficult as it is necessary to provide credibility to the continuance of a trade regime. Third, the manner in which the trade policy had been made at the time of the liberalization had been ad hoc, with little attention paid to a systematic approach to institutional issues. Finally, many of the countries had become GATT members in late 1980s. GATT conventions for anti-dumping, countervailing and the provision of safeguards were not followed at that time but were planned to be adopted at a later date. ${ }^{9}$

In Argentina almost all trade-related functions were carried out by the Ministry of the Economy. The responsibilities for external trade negotiations were shared with the Foreign

9 J. Michael Finger has noted that GATT provisions regarding "exceptional protection" make political rather than economic sense. See Finger, 1995. 
Ministry. ${ }^{10}$ No independent statutory body existed to review trade policy or its practice, at the time of the trade liberalization. Nearly all the trade reforms were introduced through resolutions without laws passed for the purpose to enable the reforms to be grounded in a well defined legal framework. Laws such as buy Argentinean goods (compre argentina) passed in 1963 did exist however, reflecting the earlier mind set regarding import substitution based industrialization. They continued on the books during the liberalization. They were not enforced at the time and were later rescinded. The trade reforms, as radically different as they were, came to be based on resolutions and decrees with implementing institutions remaining unchanged. Laws require some support and consensus from the opposition, while decrees require only agreement within the cabinet. " While the use of decrees provides speed, it also permits somewhat easier modification of policies in the future and creates uncertainty as to whether a particular policy can be reversed by a future government.

Chile introduced one of the most wide-ranging trade reforms for any country in 1974. By 1979 a uniform tariff of $10 \%$ was adopted with the only exception being the import tariffs on motor cars. However, no attempts were made to change the institutional framework despite the radical trade policy reforms. The main reform was led by the Minister for the Economy. ${ }^{12}$ The trade liberalization led to uniform protection with tariffs as the only form of protection. The latter being the hall mark of a liberal trade regime. It also facilitated transparency of incentives. However. some exemptions were granted even by Chile during its liberalization for agriculture and motor cars.

Colombia`s most recent trade liberalization was undertaken in 1991. Because the country had excess reserves and the administration was convinced that rapid liberalization could bring rapid benclits. trade liberalization was accelerated. particularly on the import side. However, at the time the policy changes were being made. Colombia had a complicated paraphernalia of institutions that were making and implementing trade policy. It had a powerful trade

\footnotetext{
"iATl. Argentina: Trade Policy Review. Geneva. 1992.

11 Julio Berlinski, 1994

I: Vittorio Corbo. 1991.
} 
implementation authority called the Instituto Colombiano de Comercio Exterior (INCOMEX) and complicated rules governing duty drawbacks, export credit and export certificate schemes. These remained in place.

In Jamaica too, trade reforms were taking place in a pre-existing protectionist institutional framework. There, trade policy making was largely the responsibility of the Ministry of Finance. Trade policies were closely coordinated with foreign exchange allocation. Import licenses and access to foreign exchange had been administered with the close cooperation between the Ministry of Finance and the Central Bank.

The situation in Trinidad and Tobago was not very different from Jamaica. Decisions regarding changes in tariff, QRs, stamp duties, surcharges, exemptions and the like were made by the Ministry of Finance, under advice of the Industrial Development Corporation that reported to the Minister of Trade. That institution was responsible for granting concessions to domestic producers while the Export Development Corporation provided "concessions" such as duty free imports to exporters. When trade liberalization took place in late 1992, the institutional arrangements for trade policy making continued as before.

In Uruguay too, trade liberalization was not accompanied by any change in the institutions in charge of trade policy making. Nor were the laws changed in a significant way to match the more liberal trade regime that came into existence. Trade policy decision making was done by the Minister of the Economy and Finance. The implementing authority was the Office of the Planning and the Budget. ${ }^{13}$

To summarize, based on the experiences of the countries considered here, no country attempted to change its institutional structure at the time of the trade liberalization. In some cases, the liberalizations were radical and represented a complete change in the trade policy framework. These were not policy changes alone but regime changes whenever the entire basis

${ }^{13}$ Gustavo Michelin "Uruguay Post Trade Liberalization Issues," CERES, Montevideo, 1994 (mimeo). 
for the existing policy framework was changed. It was only later that institutional changes were put in place to bring about a conformity of trade policy with the institutional aspects of trade policy making.

\section{Post Trade Liberalization Experiences}

The six countries that are considered here had varied experience with regard to trade liberalization experiences. This diversity in experiences arose from their different sizes, resource endowments, different times and speeds of trade liberalizations. Yet, they also share new and common experiences. There have been few instances of reversals in trade policy making. But they have not changed the character of the trade regime in terms of their policy direction or content. The reversals to date have been somewhat marginal. They have taken the form of new instruments such as wide use of reference prices and customs valuation, anti-dumping and the promotion of one sector over another through differential domestic taxes and subsidies.

It is not surprising that there have been some partial reversals. The main contention of the political economy approach to policy reform is validated in these reversals. The political coalition that led to the liberalization cannot be sustained for long periods. In addition, there have been pressures that were building up for protection given that the traditional weapons of choice for protection tariffs and QRs are proscribed by national policies adopted during this period. All the countries in this group had become members of GATT, which precluded the flagrant violation of the relevant codes. However, the pressures for protection arise from the continuing sectoral interests to secure for themselves greater private profits at the expense of consumers, other sectors which use the protected product as an input and exports which are hurt through import protection. The pressures manifest themselves in new types of protection commonly called "exceptional protection" such as antidumping, countervailing duties and subsidies. There has been additional pressure brought about by the large capital inflows after the debt crisis of the early eighties. Capital inflows have led to appreciations in the exchange rates and, the appreciations in turn have reduced the domestic currency prices of imports and exports. 
In the meantime, there have been significant changes in the domestic institutional environment since it was not dealt with at the time of the trade liberalizations. It must have become apparent that appropriate institutions were needed to deal with the pressures for protection. They are also needed to advance the agenda for further liberalization. In addition trade policy making institutions had to be adopted to the provisions of the Uruguay Round.

In Argentina, there has been an increase in the variance of protection while the average level of protection may have remained unchanged. There has been an attempt to extend the special regime accorded to the motor car industry to other industries. Thus, other industries are allowed reduced import duties for exports, if they enter into an agreement with the Ministry of Trade to convert their industries to export more. These industries are allowed to import capital goods at a lower tariff rate with an agreement with the Ministry of Industry. The statistical tax was raised from $3 \%$ to $10 \%$ and later returned to $3 \%$. Anti-dumping activity had increased, specially directed against Brazil which had a depreciated exchange rate before the "Plano Real," relative to the Argentinean peso. The latter has been fixed in relation to the US dollar as a part of the Convertibility Plan. The final outcome of these reversals has not been so much an increase in protection, as much as an increase in the variance of protection. The three tier tariff rate which was adopted in 1991, became a seven tier tariff structure. There has also been an attempt to fine-tune export incentives, with different coefficients prescribed for different "production chains" to determine tariff reimbursement rates. Three basic reasons can be adduced for this partial reversal. First, the appreciation of the peso given its fixed nominal exchange rate, even though domestic inflation rate has remained unprecedently low for Argentina. Second, an incomplete trade reform had reduced automobile protection but did not eliminate it. This has given other industries the occasion to ask and receive special concessions. Finally, until last year, there has not been a transparent mechanism to provide exceptional protection. In other words, the absence of a proper safeguard mechanism had created the opportunity for sectoral interests to ask for sector specific protection when import threats appeared such as in the case of sports shoes and certain kinds of paper. 
In Chile there has been very little departure from the pattern of protection observed since 1986, despite strong pressures to grant protection to few of the dominant sectors. Agriculture has been able to secure a measure of protection through the price band mechanism. Reference prices to protect some activities have become a weapon of choice. Anti-dumping measures have also increased compared to the past. These minor departures from a highly liberalized trade regime do not herald a change in policy. If anything, Chile is more committed to free trade than ever before. ${ }^{14}$ The new democratically elected government of Chile adopted the trade policies of the earlier regime without great fanfare. This shows that Chile has remained steadfastly committed to free trade. As a part of the effort to resist pressures for protection, Chile adopted several institutional arrangements.

Colombia has also held on to liberalized trade. The Gaviria administration was strongly committed to the idea of liberal trade. It accelerated the rate of trade reforms. The tariff levels that were to prevail in 1994 were reached in 1991. It eliminated almost all QRs, lowered tariffs significantly and stopped the allocation of foreign exchange based on import licenses. There have been few anti-dumping actions, though they are not described as such. These relate to the poultry industry and textiles. Meanwhile, agriculture protection continued.

There has been very few if any reversals in Jamaica. One reason for this is that it did not have as low protection levels as Argentina, Colombia or Chile. Even after it had liberalized, Jamaica had higher levels of protection relative to its competitors. For example, it had a tariff level of $5-30 \%$ in 1994. Jamaica has to confirm to the CARICOM common external tariff or change them unilaterally. It has taken the former path and has committed to adopt $5-20 \%$ range CET by 1997. Although Jamaica has resolved not to use reference prices, it has de facto continued to use them in the absence of implementing the GATT valuation system. In the meantime, stamp duties on some agriculture imports have continued.

\footnotetext{
if However, automobile protection has continued because of contracts with motor car producers that had been signed some 20 years ago. These contracts will be renegotiated in the future with lower or no protection.
} 
Similarly, Trinidad and Tobago has had had few changes in the levels of protection. Although the stamp duties were removed, surcharges on agricultural imports have continued. They are to be removed by 1997 . This resulted from duty exemptions that helped to raise effective protection with reduced nominal protection on imported inputs. QRs were reimposed on the import of chicken parts from the U.S.

Uruguay also experienced reversals in the form of giving additional concessions to the automobile industry and the adoption of a price band measure for agriculture that is protectionist.

\section{Institutional Changes}

Constant protectionist pressure has led to partial reversals. This induced a host of institutional changes to the trade regimes in these countries for several reasons. First, the issue had not been addressed before. Second, the possibility of policy reversals may have encouraged the governments to meet the challenge of matching institutional reform with the policy changes. Third, the Uruguay Round negotiations were going on during the post liberalization period and the need arose to make institutional arrangements consistent with the new GATT rules.

Argentina has established a National Trade Commission charged with the responsibility of advising the government on trade policy-making and for considering the requests for protection on a continuous basis. The Commission is linked to the Secretary of Trade and Investment who reports to the Minister of Economy. The Commission is expressly charged with making investigations regarding unfair trade practices, study safeguards, analyze the extent of injury said to occur and to suggest remedies to alleviate injury. Earlier, any import price that was below $15 \%$ of the domestic price in Argentina could be countered by a reference price which would equate that the import price to the domestic market price. Following the creation of the commission, a process for contingent protection is to be established.

Chile established a National Commission on Trade in 1986. Its purpose was to determine the extent of "distortions" in the world price of imports. The Commission is by law 
composed of the President of the country, the Ministers of Finance, Economy and External Affairs. Its purpose was to consider complaints against unfair trade practices, undertake neutral inquiries and establish the veracity of the claims of injury and remedies, if there is demonstrable injury. The process is highly transparent. The request for an inquiry has to be published within thirty days of the application, and the Commission has to give the results of its analysis within ninety days. The remedies proposed could be and indeed were, tariff surcharges to the extent of the apparent subsidy.

Colombia established a Foreign Trade Ministry getting rid of a highly protectionist import administration led by INCOMEX, an arch-typical import licensing regime. Earlier, the trade institutional structure was prescribed by the Law of 444 of 1967. This law gave INCOMEX, among others, power to implement trade policy. INCOMEX had administered the quota regime, provided import licenses on pre-existing plans and monitored the progress of sectoral compliance. The 1992 reforms changed all that. With the establishment of the new Foreign Trade Ministry, the government hoped to have uniform incentives. It established a very stringent criteria for safeguards, countervailing and anti-dumping which are subject to public inquiry. Under the new Colombian law, actual injury must be demonstrated. It is not sufficient to say that there would be potential injury. The relief granted is restricted to one year. In this sense, Colombia's law is more stringent than that of the GATT to provide contingent protection.

Jamaica has also changed its trade policy making apparatus. While the decisions are still taken at the ministerial level, other agencies are consulted when anti-dumping and countervailing issues are to be contemplated. A consumer representative was added to the anti-dumping committee. A one year sun-set clause was introduced for anti-dumping. And an expiration date was defined for countervailing duties.

In Trinidad and Tobago, the main change in trade policy making institutions was the creation of three corporations led by the Trade and Tourism Development Corporation to administer trade, industry and export development concessions including exceptional protection. 
The government is in the process of defining an appropriate framework for the new institutions to operate.

Uruguay had a tariff commission in the past, but it had not been used much. In 1992, Uruguay established an Application Commission which was to consider and help resolve issues relating to the injury of domestic industry due to import surges. An application for relief from import competition has to be evaluated within thirty days. Another ninety days are permitted for a decision by the Application Committee to grant or deny the application. But it is the Minister of Finance who will decide on the type of measures to be adopted should a situation of dumping, subsidization or similar unfair trade practice is directed at domestic industry. Uruguay has not used anti-dumping before, since it did not want to point an accusative finger at its powerful northern neighbors. It was inhibited against the use of countervailing duties as other countries would also ask that the same item be countervailed in their own countries. There was also the fear of retaliation if anti-dumping action is taken.

The institutional reforms identified above lend themselves to a few generalizations. First, institutional changes that support the liberalized trade regimes always followed rather than led policy reform. Perhaps this is an inevitable sequence given the extent of effort required to bring about institutional changes, with its political economy ramifications. Second, there has been an attempt to give central focus to trade policy making institutions by moving it from different agencies to a single agency. This is the experience of Argentina, Chile, Colombia and Uruguay. In the two Caribbean countries, the Ministries of Finance continue to be involved with trade policy making even though in Trinidad and Tobago, three corporations were put in charge of administering trade, industry and foreign concessions. The centralization of trade policy decisions would serve national interests better than if a sectoral ministry were given that responsibility. Third, despite the liberalizations, some sectors have continued to receive protection. In the countries considered here, the common sectors protected are automobiles, textiles and agriculture. The protection of the automobile sector is explained more by historical reasons. It particular, the automobile industry was able to wield lobbying power through it association with past governments based on large rents earned due to protection and forging 
close links to decision making agencies. Textile protection can be explained by the importance of the labor movement in the textile sector and the contagion effects of the export quotas administered through the Multi-Fibre Arrangement. Agriculture protection has continued due to the difficulties of adjustment from the lack of easy alternative employment opportunities for the rural workers and the public interest in maintaining stability of their incomes. Fourth, there have been attempts to introduce measures to provide relief to activities which have been subject to increased competition from imports, on the grounds of trade practices. Many countries have used reference prices more than anti-dumping. Proper GATT consistent safeguards have not been adopted. ${ }^{15}$ Equally, countries have desisted a wide use of anti-dumping for the effort involved. the fear of retaliation and that others would follow the lead of one country if it were to target a particular exporter. Fifth, many countries have made their institutions more consistent with GATT rules than in the past even though those rules themselves were evolving. The standards required for establishing and implementing a safeguards system are more stringent than that of using anti-dumping. Even so, countries in the group have used reference prices which operate like anti-dumping actions. Finally, there were attempts to provide support for export interests through public interventions. Chile gives subsidies to small and medium size exporters under PROCHILE. Columbia reformed its plethora of promotion schemes to be confined to a Bank for Foreign Trade and an Export Promotion Trust. Trinidad and Tobago created an Export Development Corporation for the purpose.

\section{Lessons and Remedies}

Based on these experiences, the first lesson is that the largest challenge to maintaining open trade regimes on the policy side arises from the macroeconomic situation. In the past. many of the trade liberalizations were reversed due to macroeconomic crises arising from unsustainable current account positions and appreciation of the exchange rate. While there has not been a significant reversal in the countries discussed above. some partial reversals have

1. Safeguards provide the political cover to protect. See Finger 1995. 
taken place. ${ }^{16}$ They could be said to be associated with exchange rate appreciations due to capital inflows. In the six countries considered here, It has been shown that what the reversals did mainly was to lead to departures from uniformity rather than a significant increase in overall protection. ${ }^{17}$ Chile, which had reduced protection to $10 \%$ uniform tariff in 1979 , had to raise the average tariff to $35 \%$ in 1983, because the Manufacturers Association was able to lobby successfully during the economic crisis of 1983 . It was able to lower protection when the economy recovered and saw strong growth.

The second lesson is that trade policy making has to be kept under constant review if reversals are to be avoided. The cost of protection must be publicized and communicated to the community at large. For example, the cost of maintaining a job in the automobile industry or in textiles would serve as a good indicator of trade distortions. Society would not support protection of automobile production when the cost of maintaining a job in the automobile industry is more than ten fold of per capita income as in some cases. A report prepared under the Chairmanship of Fritz Leutwiler before the start of the Uruguay Round noted that governments should be required to explain and defend their overall trade policies. ${ }^{18}$ In fact, that report proposed the preparation of a protection balance sheet showing the various cost of protectionist devices ranging from border measures such as tariffs and quotas to domestic industry specific subsidies. Effective rates of assistance that denote the cost of non-border measures have been used extensively during the negotiation of the Uruguay Round to demonstrate the costs of domestic subsidies in agriculture in Europe. This type of information would be useful as counterweight to the lobbying efforts of entrenched protectionist interests in developing countries as well.

\footnotetext{
16 Some countries not discussed here, Venezuela and Brazil, have seen more substantial reversals in the form of foreign exchange controls in the case of the former and raising import duties in the case of the latter.

${ }^{17}$ Corbo, 1991.

18 Trade Policies for a Better Future, Proposals for Action, GATT, Geneva, 1985.
} 
Third, there must be measures that help with the adjustment of domestic activities to short run price movements that do not lead to protection. The danger is that the assistance can become permanent and could be unrelated long price term trends. Cash grants to farmers independent of production levels, a good safeguard mechanism and pre-announced liberalizations are means that are available to prevent slippage in trade policy when there are exogenous shocks such as a price collapse. Agriculture has been successful in receiving and maintaining protection precisely because it has little recourse to adjustment. Protection is extended in lieu of adjustment. In addition, if special attention is given to the farmers who have limited opportunities to diversify their resource use, there will not be a very sympathetic hearing for protection, for which whole society has to pay a price.

Fourth, external commitments can be used to discourage a return to protection through GATT bindings and CETs agreements under customs unions. The bindings can help to put domestic protectionist interests under notice that raising protection would contravene international agreements and obligations. Similarly, a limit put on a CET could provide a ceiling on protection. However, care must be taken to prevent CET exemptions from taking place as has happened under CARICOM. There is a new danger that the rules of origin could become a protective device by keeping out goods of non-member countries; in that case, external commitments could inhibit freer trade.

Finally, a continuing reform agenda that extends beyond trade policies would help to maintain liberalized trade regimes and to push the trade agenda further. Reform of labor markets, domestic regulation and access to capital would allow the adjustment to changes in world price easier. This way, factors of production can be allowed to move from one activity to another smoothly and prevent the build up of pressures that lead to protection. In this sense, protection is a price that has to be paid for non-adjustment. Making adjustments easier would help to maintain open trade and push the liberalization agenda further. 


\section{Institutional Remedies and Mechanisms}

While the above lessons would serve to keep the policy frameworks open, there are institutional features that favor liberalized trade. Such institutional remedies have worked well in some cases. One well known example is the Australian Trade Commission. ${ }^{19}$ While some of its past effectiveness has been reduced due to sectoral pressures, it remains as an example of a good trade policy review device.

Many experiences of institutional remedies for maintaining liberalized trade regimes and keeping the trade regime open for further liberalization suggest that an independent advisory authority or commission such as those adopted by Argentina, Chile, and Uruguay would be a good device. These commissions use a transparent process, and are one step removed from the policy makers. It enables them to undertake inquiries without being subject to political or sectoral pressures. The principal characteristics of such an institutional arrangement can be summarized as the following:

First, make the body advisory, independent of day to day trade policy making so that it could conduct its work in a steady manner, free from administrative pressures and exigencies.

Second, inquiries into the requests for protection must be conducted in an open and transparent manner and the findings of such inquiries must be subject to public scrutiny.

Third, the procedures for granting relief such as through a safeguard mechanism must reflect all interests and parties including consumers, exporters and users of the product in question as an input.

\footnotetext{
19 John Spriggs "Towards an International Transparency Institution- Australian Style," World Economy, vol. 14, 1991.
} 
Finally, the analysis used to establish injury must conform to high technical standards and the criteria used for considering trade policies must always reflect national interests and not that of any particular sector. 
Table 1: Indicators of Trade Regimes Pre and Post Liberalization

\begin{tabular}{|c|c|c|c|c|c|c|}
\hline \multirow[t]{2}{*}{$\begin{array}{c}\text { Country } \\
{\text { (pre-liberalization, post-liberalization })^{\underline{2}}}^{\frac{2}{2}}\end{array}$} & \multicolumn{2}{|c|}{$\begin{array}{l}\text { Average Unweighted } \\
\text { Legal Tariff Rates (\%) }\end{array}$} & \multicolumn{2}{|c|}{ Tariff Range (\%) } & \multicolumn{2}{|c|}{$\begin{array}{l}\text { Coverage of QRs on Imports } \\
\text { (\% of tariff lines, unless } \\
\text { otherwise noted })^{\mathbf{b} /}\end{array}$} \\
\hline & Pre-reform & Post-reform & Pre-reform & Post-reform & Pre-reform & Post-reform \\
\hline Argentina $(1987,1991)$ & $42(p)$ & 15 & $15-115(p)$ & $5-22$ & 62 (of dom. prod.) & A few \\
\hline Chile $(1984,1991)$ & 35 & 11 & $\overline{35}$ & 11 & Minimal & $\overline{0}$ \\
\hline Colombia $(1984,1992)$ & 61 & 12 & $0-220$ & $5-20$ & 99 & 1 \\
\hline Jamaica $(1981,1991)$ & NA & 20 & NA & $0-45$ & NA & $0(3)$ \\
\hline Trinidad \& Tobago $(1989,1991)$ & NA & $41(\mathrm{p})$ & NA & $0-103(p)$ & NA & A few \\
\hline Uruguay $(1987,1992)$ & 32 & 18 & $10-55$ & $12-24$ & 0 & 0 \\
\hline
\end{tabular}

Source: Alam and Rajapatirana, 1993.

a/ The pre-liberalization year was chosen to contrast with the post trade liberalization year. It denotes the undertaking of some significant liberalization measures, but not the exact year of trade liberalization itself, e.g., Chile liberalized its trade regime in 1974 and Colombia in 1991.

b/ Even where tariff line coverage is small, domestic production coverage may be significant. 


\section{References}

Alam, Asad and Sarath Rajapatirana. 1993. Trade Policy Reform in Latin America and the Caribbean in the 1980s. World Bank Working Paper No. 1104.

Berlinski, Julio. 1994. Post Trade Liberalization Issues in Argentina. Instituto Di Tella. Buenos Aires.

Bhagwati, Jagdish. 1978. Foreign Trade Regimes and Economic Development Anatomy and Consequences of Exchange Control Regimes. Cambridge, Mass.: Ballinger.

Corbo, Vittorio. 1991. Trade Reforms in Chile: An Update. Santiago. Mimeo.

Corden, W. Max. 1974. Trade Policy and Economic Welfare. Oxford: Clarendon Press.

Edwards, Sebastian. September 1993. Openness, Trade Liberalization and Growth in Developing Countries. Journal of Economic Literature, vol. 31, pp. 1358-1393.

Finger, J. Michael. 1995. Safeguard Mechanisms: Their Design and Operation. World Bank. Mimeo.

Krueger, Anne O. 1978. Foreign Trade Regimes and Economic Development: Liberalization Attempts and Consequences. Cambridge, Mass.: Ballinger

Laird, Sam and Patrick Messerlin. June 1990. Institutional Reform for Trade Liberalization. The World Economy, vol. 13.

Leutwiler et al. 1985. Trade Policies for a Better Future: Proposals for Action. GATT, Geneva.

Little, I. M. D., Richard N. Cooper. W. Max Corden and Sarath Rajapatirana. 1993. Boom. ('risis and Adjustment: Macroeconomic Experiences of Developing ('ountries. Oxtord: Oxford University Press.

Lustig. Nora and Carlos Primo Braga. 1994. The Future of Trade Policy in Latin America. Washington, D.C.

Little, I.M.D.. and others. 1970. Industry and Trade in Some Developing (ountries. Oxford: Oxford University Press.

Michelin. Gustavo. 1994. Urmguay: POst Trade Liheralization Issues: ClERISS, Montevideo. Mimeo.

Spriggs. Jolnn. 1991. Towards an International Transparency Institution - Australian Sitste. World Lconomy, vol. 14. 
Stoeckel, Andy and Sandy Cuthbertson. 1987. The Game Plan: Successful Strategies for Australian Trade. Center for International Economics. Canberra.

Valdes, Alberto and Barry Schaeffer. 1993. Domestic Surveillance for Transparency in Agricultural Trade and price Policy: Progress Report. World Bank. 



\section{.}





\section{Policy Research Working Paper Series}

\begin{tabular}{|c|c|c|c|c|}
\hline & Title & Author & Date & $\begin{array}{l}\text { Contact } \\
\text { for paper }\end{array}$ \\
\hline WPS1450 & $\begin{array}{l}\text { Social Safety Net and the Poor } \\
\text { during the Transition: The Case of } \\
\text { Bulgaria }\end{array}$ & $\begin{array}{l}\text { Fareed M. A. Hassan } \\
\text { R. Kyle Peters, Jr. }\end{array}$ & May 1995 & $\begin{array}{l}\text { F. Smith } \\
36072\end{array}$ \\
\hline WPS1451 & Tunisia's Insurance Sector & Dimitri Vittas & May 1995 & $\begin{array}{l}\text { P. Infante } \\
37642\end{array}$ \\
\hline WPS1452 & $\begin{array}{l}\text { The 1985-94 Global Real Estate } \\
\text { Cycle: Its Causes and Consequences }\end{array}$ & Bertrand Renaud & May 1995 & $\begin{array}{l}\text { R. Garner } \\
37670\end{array}$ \\
\hline WPS1453 & $\begin{array}{l}\text { Air Pollution and Mortality: Results } \\
\text { from Santiago, Chile }\end{array}$ & $\begin{array}{l}\text { Bart Ostro } \\
\text { Jose Miguel Sanchez } \\
\text { Carlos Aranda } \\
\text { Gunnar S. Eskeland }\end{array}$ & May 1995 & $\begin{array}{l}\text { C. Bernardo } \\
37699\end{array}$ \\
\hline WPS1454 & Child Labor: A Review & $\begin{array}{l}\text { Christiaan Grootaert } \\
\text { Ravi Kanbur }\end{array}$ & May 1995 & $\begin{array}{l}\text { M. Youssef } \\
34614\end{array}$ \\
\hline WPS1455 & $\begin{array}{l}\text { Tentative First Steps: An Assessment } \\
\text { of the Uruguay Round Agreement } \\
\text { on Services }\end{array}$ & Bemard Hoekman & May 1995 & $\begin{array}{l}\text { F. Hatab } \\
35835\end{array}$ \\
\hline WPS1456 & $\begin{array}{l}\text { Equity Markets, Transaction Costs, } \\
\text { and Capital Accumulation: An } \\
\text { Illustration }\end{array}$ & $\begin{array}{l}\text { Valerie R. Bencivenga } \\
\text { Bruce D. Smith } \\
\text { Ross M. Starr }\end{array}$ & May 1995 & $\begin{array}{l}\text { P. Sintim-Aboagy? } \\
38526\end{array}$ \\
\hline WPS1457 & $\begin{array}{l}\text { Does Decentralization Increase } \\
\text { Spending on Public Infrastructure? }\end{array}$ & $\begin{array}{l}\text { Antonio Estache } \\
\text { Sarbajit Sinha }\end{array}$ & May 1995 & $\begin{array}{l}\text { WDR } \\
31393\end{array}$ \\
\hline WPS1458 & $\begin{array}{l}\text { Credit Policies: Lessons from East } \\
\text { Asia }\end{array}$ & $\begin{array}{l}\text { Dimitri Vittas } \\
\text { Yoon Je Cho }\end{array}$ & May 1995 & $\begin{array}{l}\text { P. Infante } \\
37642\end{array}$ \\
\hline WPS1459 & $\begin{array}{l}\text { Pension Funds in Central Europe } \\
\text { and Russia: Their Prospects and } \\
\text { Potential Role in Corporate Governmen }\end{array}$ & $\begin{array}{l}\text { Dimitri Vittas } \\
\text { Roland Michelitsch } \\
\end{array}$ & May 1995 & $\begin{array}{l}\text { P. Infante } \\
37642\end{array}$ \\
\hline WPS1460 & $\begin{array}{l}\text { Efficiency and Equity Considerations } \\
\text { in Pricing and Allocating Irrigation } \\
\text { Water }\end{array}$ & $\begin{array}{l}\text { Yacov Tsur } \\
\text { Ariel Dinar }\end{array}$ & May 1995 & $\begin{array}{l}\text { C. Spooner } \\
32116\end{array}$ \\
\hline WPS1461 & $\begin{array}{l}\text { Stock Market Development and Firm } \\
\text { Financing Choices }\end{array}$ & $\begin{array}{l}\text { Asli Demirgüç-Kunt } \\
\text { Vojislav Maksimovic }\end{array}$ & May 1995 & $\begin{array}{l}\text { P. Sintim-Aboagye } \\
38526\end{array}$ \\
\hline WPS1462 & $\begin{array}{l}\text { Stock Market Development and } \\
\text { Financial Intermediaries }\end{array}$ & $\begin{array}{l}\text { Asli Demirgüç-Kunt } \\
\text { Ross Levine }\end{array}$ & May 1995 & $\begin{array}{l}\text { P. Sintim-Aboagye } \\
38526\end{array}$ \\
\hline WPS 1463 & Rural Nonfarm Employment: A Survey & $\begin{array}{l}\text { Jean O. Lanjouw } \\
\text { Peter Lanjouw }\end{array}$ & May 1995 & $\begin{array}{l}\text { J. Shafer } \\
85581\end{array}$ \\
\hline
\end{tabular}




\section{Policy Research Working Paper Series}

Title

WPS1464 How Does the North American Free Trade Agreement Affect Centra: America?

WPS1465 Post Trade Liberalization Policy and institutional Challenges in Latin America and the Caribbean
Author

Date

Edward E. Leamer

Altonso Guerra

Martin Kautman

Boris Segura

Sarath Rajapatirana
Contact for paper

May 1995

S. Vallimont 37791

May 1995

J. Troncoso 37826 